Penelitian

\title{
Persepsi Dokter Hewan Praktisi Hewan Kecil terhadap Telemedicine di Masa Pandemi Covid-19
}

\author{
Perception of Telemedicine on Small Animal Veterinary Practice \\ During Pandemic COVID-19
}

\author{
Muhammad Fadly Aulia'*, Dwi Cipto Budinuryanto, ${ }^{1,3}$, Okta Wismandanu ${ }^{1,2}$ \\ 'Program Studi Kedokteran Hewan, Fakultas Kedokteran, Universitas Padjadjaran, Jl. Raya Bandung Sumedang KM.21, \\ Hegarmanah, Kecamatan Jatinangor, Kabupaten Sumedang, Jawa Barat, Indonesia \\ 2Departemen Ilmu Kesehatan Masyarakat, Fakultas Kedokteran, Universitas Padjadjaran, Jl. Eijkman No. 38, \\ Bandung, Jawa Barat, Indonesia \\ 3Departemen Hewan Produksi, Fakultas Peternakan, Universitas Padjadjaran, Jl. Raya Bandung Sumedang KM.21, \\ Hegarmanah, Kecamatan Jatinangor, Kabupaten Sumedang, Jawa Barat, Indonesia \\ *Penulis untuk korespondensi : okta.wismandanu@unpad.ac.id \\ Diterima 28 Januari 2021, Disetujui 15 Juni 2021
}

\begin{abstract}
ABSTRAK
Telemedicine didefinisikan sebagai diagnosis jarak jauh dan perawatan pasien dengan memanfaatkan teknologi informasi dan komunikasi. Baru-baru ini telemedicine menjadi topik yang menarik di bidang kedokteran hewan. Persepsi dokter hewan khususnya praktisi hewan kecil terhadap sesuatu hal termasuk telemedicine dipengaruhi banyak faktor, contohnya: karakteristik individu dan pengalaman hidup. Penelitian ini bertujuan untuk mengetahui persepsi dokter hewan praktisi hewan kecil terhadap telemedicine. Penelitian ini diharapkan menjadi bahan acuan penelitian selanjutnya dan dapat menjadi masukan dalam pelaksanaan/penerapan telemedicine pada praktiknya. Desain penelitian ini adalah penelitian dengan metode deskriptif, dimana metode pengambilan sampel menggunakan kuisioner yang diisi oleh dokter hewan praktisi hewan kecil secara online melalui platform Google Form. Hasil penelitian menunjukkan bahwa pandemi tidak berdampak terhadap layanan dokter hewan. Namun terjadi adaptasi terhadap tata cara praktik. Responden bersikap netral terhadap penerapan telemedicine, namun mayoritas responden yang telah menerapkan telemedicine beranggapan bahwa penerapan telemedicine berdampak baik terhadap layanan kesehatan. Banyak hambatan yang dirasakan oleh responden dalam menerapkan telemedicine, contohnya: karakteristik klien, legalitas praktik telemedicine, permasalahan biaya sebagai penghargaan jasa, dan kesulitan dalam diagnosa sehingga membutuhkan pemeriksaan lanjutan.
\end{abstract}

Kata kunci: Persepsi, dokter hewan praktisi hewan kecil, pandemi, dan telemedicine

\begin{abstract}
Telemedicine is defined as remote diagnose and patient care using telecommunications technology. Recently telemedicine has become an interesting topic in the field of veterinary medicine. The perception of veterinarians, especially small animal practitioners, about telemedicine is influenced by many factors, for example: individual characteristics and life experiences. This study aims to determine the factors that influence veterinarians' perceptions of telemedicine. This research is expected to become a reference for durther research and can be an input in implementing of telemedicine. The design of this study is descriptive method, where the sampling method uses a questionnaire filled out by small animal practitioners trough the Google Form platform. The results showed that the pandemic had no impact on veterinary services. But there is an adaptation of practice procedure. Respondents are neutral towards the application of telemedicine, but the majority of respondents who have implemented telemedicine think that the application of telemedicine has a good impact on health services. There are many obstacles felt by respondents in implementing telemedicine, for example: client characteristics, legality of telemedicine practice, problems of cost as a service reward, and difficulties in diagnosis that required further examination.
\end{abstract}

Keywords: Perception, small animal practice veterinary, pandemic, telemedicine 


\section{PENDAHULUAN}

Persepsi memiliki banyak arti atau definisi. Menurut Kamus Besar Bahasa Indonesia, persepsi adalah tanggapan (penerimaan) langsung dari sesuatu. Persepsi juga dapat diartikan sebagai pandangan dan penafsiran atas sesuatu. Banyak faktor yang mempengaruhi persepsi seseorang, salah satunya pengalaman hidup masing-masing individu. Dengan pengalaman hidup yang berbeda-beda, setiap orang dapat memiliki persepsi yang berbedabeda pula. Dalam penelitian ini, persepsi dokter hewan praktisi hewan kecil terhadap penerapan telemedicine dapat berbeda-beda pula.

Komunikasi dalam pelayanan kesehatan merupakan penentu penting dalam kualitas pelayanan, hasil pelayanan dan kepuasan pasien. Keterampilan komunikasi dalam kedokteran hewan menjadi fokus dan perhatian topik yang terus berkembang. Saat ini informasi tentang kesehatan hewan peliharaan mudah didapatkan dengan mengakses internet, sehingga klien mudah mendapatkan informasi yang menyebabkan mereka ingin terlibat aktif dalam perawatan hewan peliharaan mereka (Kogan et al., 2012). Seiring dengan kemajuan teknologi dan informasi, dokter hewan juga dituntut untuk bisa melakukan kewajiban client education secara langsung maupun online.

Di zaman sekarang, hewan kecil atau hewan peliharaan yakni anjing dan kucing menjadi hewan yang banyak dipilih sebagai hewan peliharaan. Menurut studi, memelihara hewan di rumah memiliki manfaat salah satunya penghilang stress (Haire, 2010). Banyaknya hewan peliharaan menyebabkan kebutuhan akan dokter hewan praktisi hewan kecil juga semakin tinggi.

Penggunaan bidang komunikasi yang berkembang dengan cepat perlu dimanfaatkan oleh masyarakat di berbagai sektor. Teknologi Informasi dan Komunikasi (TIK), yang meliputi alat untuk memfasilitasi komunikasi, pemrosesan dan transmisi informasi dengan tujuan meningkatkan kesehatan telah cepat berkembang. TIK dipandang oleh banyak orang sebagai alat yang memiliki peran sangat penting dalam meningkatkan akses dan kualitas layanan kesehatan untuk publik (Lindberg et al., 2013).

Kemajuan teknologi telah membuka lebih banyak media interaksi pasien dan dokter. Diantara media yang ada, email dan media sosial sangat potensial untuk meningkatkan komunikasi (Lee et al., 2015) Aktivitas dalam media sosial sekarang adalah aktivitas paling populer di internet. Platform media sosial membantu memfasilitasi komunikasi dan berbagi informasi dalam forum publik, dan dirancang untuk memudahkan berbagi konten dan berkomunikasi dengan keluarga dan teman (Kogan et al., 2015). Oleh karena itu, menyediakan seperangkat alat kesehatan medis lainnya dapat digunakan untuk terhubung dengan klien dan pasien.

Wabah COVID-19 yang menyebar ke berbagai negara di dunia menyebabkan Organisasi Kesehatan Dunia (WHO) menyatakan darurat kesehatan global pada 30 Januari 2020 (Ahmed \& Quadeer, 2020). WHO menganjurkan/menginstruksikan menjaga jarak atau social distancing setidaknya 1 meter dari orang lain. Pemerintah Indonesia melalui Peraturan Pemerintah No.21 Tahun 2020 menyebut Pembatasan Sosial Berskala Besar bagian respon kedaruratan kesehatan masyarakat. Hal ini berdampak terhadap semua sektor, termasuk sektor kesehatan yakni proses pelayanan kesehatan dokter hewan terhadap klien dan pasien.

Urusan kesehatan hewan dilakukan dengan pendekatan pemeliharaan, peningkatan kesehatan (promotif), pencegahan penyakit (preventif), penyembuhan penyakit (kuratif), dan pemulihan kesehatan (rehabilitatif) yang dilaksanakan secara menyeluruh, terpadu, dan berkesinambungan (Iqbal, 2011). Klien yang memiliki akses ke dokter hewan melalui telemedicine dapat membantu meringankan kegelisahan yang dimiliki pemilik hewan peliharaan, sekaligus membantu membangun kepercayaan mereka pada dokter hewan. Telemedicine juga dapat membebaskan waktu dokter hewan karena janji di klinik akan terbatas pada pasien yang perlu dilihat secara langsung.

\section{BAHAN DAN METODE}

Penelitian ini menggunakan metode deskriptif, dimana metode pengambilan sampel menggunakan kuisioner yang diisi secara online melalui platform Google Form. Responden diminta mengisi data diri dan memberikan pendapatnya terhadap telemedicine. Pertanyaan yang diberikan memiliki pilihan jawaban yang beragam, seperti: "Ya" atau "Tidak", skala likert 1-5, dan memilih maupun menuliskan pendapat. Pada awalnya kuisioner disebar melalui Pengurus Besar Perhimpunan Dokter Hewan Indonesia (PB PDHI) dan Asosiasi Dokter Hewan Praktisi Hewan Kecil Indonesia (ADHPHKI). Selanjutnya penyebaran kuisioner dilakukan dari grup ke grup dan juga dengan mendatangi beberapa klinik secara langsung. Jumlah sampel yang dibutuhkan sebanyak 106 dokter hewan praktisi hewan kecil di Indonesia. Namun, pada akhirnya data yang diperoleh adalah 74 data responden. Kemudian data dikelompokkan dan 
dianalisis dalam bentuk angka dan persentase lalu dideskripsikan.

\section{HASIL}

Setelah dilakukan penyebaran kuisioner, terkumpul data 74 responden yang melakukan pengisian kuisioner secara online. Berikut data sosiodemografi responden yang disajikan pada Tabel 1.

Responden paling banyak mengisi kuisioner yakni berasal dari rentang umur 31-40 tahun yakni lebih dari $40 \%$. Mayoritas responden berjenis kelamin perempuan yakni sebesar $57 \%$ dari 74 responden. Selanjutnya, responden diminta untuk mengisi alamat praktik. Lalu peneliti mengelompokkan wilayah praktik ke dalam perkotaan atau pedesaan sesuai data pada Badan Pusat Statistik (BPS). Setelah data dikelompokkan, didapatkan sebesar $95,9 \%$ responden melakukan praktik di wilayah perkotaan atau urban.

Responden diminta pendapatnya terhadap dampak pandemi terhadap pelayanan kesehatan hewan di tempat dokter berpraktik. Sebesar 34\% responden menjawab netral dan secara keseluruhan responden beranggapan bahwa pandemi tidak berdampak negatif atau positif terhadap pelayanan kesehatan hewan di tempat praktik. Mayoritas responden yakni 55\% sangat setuju bahwa pandemi mempengaruhi tata cara praktik yang dilakukan, contoh dengan adanya pembatasan jarak atau pembatasan pasien.

Sebanyak 34\% responden setuju dengan pernyataan "Telemedicine adalah pengiriman layanan kesehatan dimana pasien dan penyedia layanan kesehatan dipisahkan oleh jarak". Hal ini menandakan mayoritas responden tau dan paham tentang telemedicine. Lebih dari 50\% responden telah menerapkan telemedicine saat praktik. Dan 34\%-nya baru menerapkan telemedicine saat pandemi. Ketika ditanya "Apakah telemedicine akan tetap dilakukan pada masa setelah pandemi?", lebih dari $70 \%$ akan tetap menerapkan telemedicine setelah pandemi selesai atau kembali normal.

Pada pertanyaan "Telemedicine perlu diterapkan di masa pandemi sekarang?", sebanyak 39\% responden memilih netral. Dan pada pertanyaan lainnya yakni "Apakah setuju dengan penerapan telemedicine?", 39\% responden memilih netral juga. Dan saat ditanya "Apakah dokter mempertimbangkan untuk menerapkan telemedicine dalam praktik di masa mendatang?", mayoritas responden yakni 39\% memilih netral. Dari jawaban pada ketiga pertanyaan tersebut, mayoritas responden bersikap netral terhadap penerapan telemedicine.

Responden diminta pendapat atas penerapan telemedicine sebagai konsultasi, alat bantu screening awal, monitoring setelah tindakan medis (contohnya post-operasi), serta sebagai peneguhan diagnosa dan peresepan obat. Sebanyak $34 \%$ responden setuju terhadap penerapan telemedicine sebagai konsultasi. Sebanyak 36\% setuju terhadap penerapan telemedicine sebagai alat bantu screening awal. Sebanyak $45 \%$ responden setuju terhadap penerapan telemedicine sebagai alat monitoring setelah tindakan medis. Namun, sebanyak $47 \%$ responden sangat tidak setuju terhadap penerapan telemedicine sebagai peneguhan diagnosis dan peresepan obat.

Responden diminta memberikan pendapatnya apa saja yang menjadi hambatan dalam menerapkan telemedicine. Sebagian besar atau $66 \%$ responden

Tabel 1 Sosio-demografi

\begin{tabular}{cc}
\hline Kelompok & $\mathrm{n}$ \\
\hline Usia & $37,8 \%$ \\
20-30 tahun & $40,5 \%$ \\
$31-40$ tahun & $14,9 \%$ \\
$41-50$ tahun & $6,8 \%$ \\
$51-60$ tahun & \\
Jenis Kelamin & $43,0 \%$ \\
Laki-Laki & $57,0 \%$ \\
Perempuan & \\
Wilayah Praktik & $95,9 \%$ \\
Perkotaan & $4,1 \%$ \\
Perdesaan & \\
\hline
\end{tabular}


memilih "karakteristik klien tidak mendukung". Sebanyak $64 \%$ responden memilih "Tidak ada legalitas" sebagai kendala dalam menerapkan telemedicine. Sebanyak $45 \%$ responden memilih "other", banyak yang ditulis oleh responden namun peneliti merangkum beberapa poin, diantaranya permasalahan biaya sebagai penghargaan jasa, kesulitan dalam diagnosa, dan memerlukan pemeriksaan lanjutan.

\section{PEMBAHASAN}

Mayoritas responden yang mengisi berasal dari rentang umur 31-40 tahun. Seiring berjalannya waktu, lulusan dokter hewan di Indonesia semakin banyak. Ini ditandai dengan program studi yang dibuka di 10 tahun terakhir. Hal ini menyebabkan mayoritas responden yang mengisi kuisioner berasal dari generasi "Milenial". Mayoritas responden berasal dari berbagai daerah di Indonesia, dari Sumatera Barat hingga Papua Barat. Sedangkan 4,1\% responden lainnya atau sebanyak 3 responden berasal melakukan praktik di wilayah pedesaan atau rural. Diantaranya berasal dari Kabupaten Kaimana, Papua Barat; Kabupaten Tulungagung, Jawa Timur; dan Kabupaten Lamandau, Kalimantan Tengah.

Mayoritas responden berpendapat bahwa pandemi tidak berdampak negatif maupun positif terhadap pelayan kesehatan di tempat praktik. Hal ini bisa disebabkan karena masyarakat Indonesia yang beraktifitas seperti biasa di saat pandemi. Sehingga pandemi tidak berdampak pada pelayanan kesehatan di tempat praktik dokter hewan. Pandemi COVID-19 mungkin bisa diatasi suatu saat, namun akan ada perubahan praktik pelayanan kesehatan dalam jangka panjang. Telemedicine akan menjadi masa depan sistem pemberian layanan kesehatan (Biswas et al., 2020).

Walaupun responden beranggapan bahwa pandemi tidak berdampak negatif maupun positif terhadap layanan kesehatan dokter hewan. Organisasi Kesehatan Dunia atau WHO setelah terjadi penyebaran yang cepat dari virus SARS-CoV-2, mendeklarasikan pandemi dari COVID-19 pada 11 Maret 2020. Penyebaran COVID-19 menyebabkan lockdown atau pembatasan ruang gerak di berbagai penjuru dunia, berdampak terhadap aktifitas sehari-hari, sistem pelayanan kesehatan yakni manajemen pelayanan antara pasien terinfeksi COVID-19 dan juga pasien yang bukan terifeksi COVID-19. Pada masa pandemi
COVID-19 terjadi peningkatan dalam penggunaan telemedicine terutama di beberapa negara maju. Dampak pandemi yakni pembatasan kontak fisik dapat diatasi dengan penggunaan teknologi yakni telemedicine (Galiero et al., 2020). Mayoritas responden menilai bahwa penerapan telemedicine cenderung berdampak baik terhadap layanan kesehatan.

Pada penelitian lain disebutkan bahwa telemedicine memiliki banyak keuntungan saat diterapkan pada praktik. Berbagai platform telemedicine seperti aplikasi smartphone atau e-mail dapat membantu dokter hewan berkomunikasi lebih baik dengan klien. Contohnya, mengirim informasi kepada klien bahwa perkembangan kesehatan hewannya berangsur membaik (Teller, 2017). Menurut Dr. Divers pada tahun 2017, pelayanan kesehatan hewan tanpa physical examination atau pemeriksaan langsung dapat berbahaya dan menyebabkan medical error (Hess, 2017).

Karakteristik klien dapat berupa usia, tingkat pendidikan,maupun latar belakang sosial. Ketika karakteristik klien tidak mendukung, akan menyebabkan komunikasi yang kurang baik dan sangat mungkin terjadi misinformasi sehingga dapat menimbulkan malpraktik. Salah satu hambatan lainnya dalam menerapkan telemedicine adalah tidak adanya legalitas sebagai payung hukum serta panduan dalam menerapkan telemedicine. AVMA yakni Asosiasi Dokter Hewan Amerika telah membuat panduan bagi dokter hewan dalam menerapkan telemedicine. Salah satu syarat penerapan telemedicine adalah adanya VCPR atau Veterinarian-ClinicPatient-Relationship. VCPR dapat didapatkan dengan adanya kunjungan klien dan pasien ke klinik secara langsung.

Di Indonesia sendiri, penerapan telemedicine pada kedokteran manusia diatur pada Peraturan Menteri Kesehatan No.20 Tahun 2019. Di Brazil, pemerintah setempat masih melakukan diskusi dalam legislasi layanan telemedicine (Silva et al., 2020). Asosiasi dokter hewan memiliki peran yang penting, namun pemerintah juga memiliki peran dalam legalitas layanan telemedicine pada praktik dokter hewan. Hambatan lainnya yang dituliskan oleh responden diantaranya permasalahan biaya sebagai penghargaan jasa, kesulitan dalam diagnosis, dan memerlukan pemeriksaan lanjutan. Pada penelitian lain, Dr. Otten pada tahun 2017 mengatakan bahwa implementasi telemedicine mempengaruhi struktur tagihan 
yang dapat memuaskan klien. Dr. Divers pada tahun 2017 mengatakan bahwa penyediaan layanan telemedicine secara langsung kepada klien tanpa memeriksakannya secara langsung memiliki potensi bahaya dimana kesalahan dalam pelayanan kesehatan dapat terjadi (Hess, 2017).

Limitasi atau keterbatasan penelitian ini terletak pada proses pengumpulan data. Salah satu kendala yang dihadapi peneliti adalah jangkauan peneliti kepada subjek penelitian. Pada awal penyusunan laporan atau rancangan awal penelitian, peneliti menargetkan 106 responden sebagai subjek penelitian. Namun, setelah beberapa waktu yang mengisi hanya sekitar $70 \%$ dari target. Sehingga peneliti harus merubah metode penelitian untuk menyesuaikan jumlah responden. Sedikitnya responden yang dapat dijangkau berdampak juga kepada sedikitnya responden yang dikategorikan berasal dari wilayah rural/pedesaan. Terjadi bias seleksi pada awal penelitian yang disebabkan oleh adanya beberapa subjek yang menolak untuk mengisi kuisioner. Subjek menolak untuk mengisi kuisioner dikarenakan ketidaktahuan subjek dengan telemedicine.

Berdasarkan hasil penelitian, pandemi tidak berdampak negatif terhadap layanan dokter hewan praktisi hewan kecil, namun dokter hewan melakukan adaptasi terhadap layanan yang dilakukan seperti pembatasan jarak seperti yang dianjurkan oleh WHO serta pemerintah, Responden yakni dokter hewan praktisi hewan kecil bersikap netral terhadap penerapan telemedicine. Namun mayoritas responden yang telah menerapkan telemedicine, beranggapan bahwa penerapan telemedicine cenderung berdampak baik terhadap layanan kesehatan. Hambatan yang dirasakan responden dalam menerapkan telemedicine berasal dari banyak hal, diantaranya: karakteristik klien, legalitas praktik telemedicine yang mencakup tatacara dan batasan sebagai payung hukum, permasalahan biaya sebagai penghargaan jasa, dan kesulitan dalam diagnosa sehingga membutuhkan pemeriksaan lanjutan.

"Penulis menyatakan tidak ada konflik kepentingan dengan pihak-pihak yang terkait dalam penelitian ini".

\section{DAFTAR PUSTAKA}

Ahmed, S. F. and Quadeer, A. A. 2020. Preliminary Identification of Potential Vaccine Targets for the COVID-19 Coronavirus (SARS CoV-2) Based on SARS-CoV Immunological Studies.
Biswas, S., Adhikari, S. D., Gupta, N., Garg, R., Bharti, S. J., Kumar, V., Mishra, S., Bhatnagar, S. 2020. Smartphone - Based Telemedicine Service at Palliative Care Unit during Nationwide Lockdown: Our Initial Experience at a Tertiary Care Cancer Hospital, pp. 31-36. Doi : 10.4103/IJPC.IJPC.

Galiero, R., Pafundi, P. C., Nevola, R., Rinaldi, L., Acierno, C., Caturano, A., Salvatore, T., Adinolfi, L. E., Costagliola, C., Sasso, F. C. $2020 . \quad$ Review Article The Importance of Telemedicine during COVID-19 Pandemic: A Focus on Diabetic Retinopathy.

Haire, M. O. 2010. Companion animals and human health: Benefits, challenges, and the road ahead, Journal of Veterinary Behavior: Clinical Applications and Research. Elsevier Inc, 5(5), pp. 226-234. Doi: 10.1016/j.jveb.2010.02.002.

Hess, L. 2017. Telemedicine: The Future of Veterinary Practice, 31(2), pp. 165-171.

Iqbal, M. 2011. NASIONAL Strengthening Animal Health Center Performance Strategy to Support National Veterinary Services, pp. 53-71.

Kogan, L. R., Schoenfeld-tacher, R. and Viera, A. R. 2012. The Internet and health information: differences in pet owners based on age, gender, and education, 100(July), pp. 197-204.

Kogan, L. R., Hellyer, W. and Stewart, S. M. 2015. Recruitment and Hiring Strategies of Private Practitioners and Implications for Practice Management Training of Veterinary Students, 42(2), pp. 97-106. doi: 10.3138/jvme.0814-085R.

Lee, J. L., Choudhry, N. K., Wu, A. W., Matlin, O. S., Brennan, T. A., Shrank, W. H. 2015. Patient Use of Email, Facebook, and Physician Websites to Communicate with Physicians: A National Online Survey of Retail Pharmacy Users, pp. 7-9. doi: 10.1007/s11606-015-3374-7.

Lindberg, B., Nilsson, C., Zotterman, D., Söderberg, S., Skär, L. 2013. Using Information and Communication Technology in Home Care for Communication between Patients, Family Members, and Healthcare Professionals: A Systematic Review, 2013.

Silva, A. B., da Silva, R. M., Ribeiro G. da. R., Guedes, A. C. C. M., Santos, D. L., Nepomuceno, C. C., Caetano, R. 2020. Three decades of telemedicine in Brazil: Mapping the regulatory framework from 1990 to 2018, pp. 1- 21. doi: 10.5281/zenodo .4012555 .

Teller, L. M. 2017. Telemedicine as a Tool in the Veterinary Practice', (January). 